\title{
Contemporary to the Future: the Classics and Digital Humanism
}

\section{Massimo Lollini, University of Oregon}

\begin{abstract}
Welcome to the third issue of Humanist Studies \& the Digital Age. It continues the discourse started with publication of the papers presented at the symposium "The Mobile Text: Studying Literature in the Digital Age" held in Rome in 2012. The current issue includes a few essays from another symposium on "Textualities in the Digital Age" held at the University of Oregon in April 2012; Art Farley summarizes the issues and papers presented in this latter symposium in the introduction that follows this editorial.
\end{abstract}

In his recent article "Memory Now," adapted from his upcoming book entitled Memory Now: Philology in a New Key, Jerome McGann holds that "[t]he fundamental obligation of philology, of the humanities, is the preservation of cultural memory." He takes his cue from Paul Connerton's How Modernity Forgets (2009) in which he laments that in the cyber world we are living in a culture of hyper-amnesia, fixed in a hyper-present, interested only in what is immediate and spectacular, and unable to envision even the short-term past as something real (Connerton 87-88). The computerized "memory banks," digital libraries and repositories, cloud computing, and aggregated network systems have made available an unprecedented scale of data and information. However, McGann suggests, data in themselves are not memory, and the software in itself is not a guarantee of cultural memory. Moreover, an exclusive focus on "radiant textualities," on flexible, dynamic means for interpretation based on digital technologies, has led to a deeper understanding of complex, multi-layered literary works but, at the same time, has relegated to the margin the problem of cultural memory. He claims that the moment has come to reconceive the relationship between the attention given to "radiant textuality" and the need to elaborate the cultural memory of our time, if we want to build a reliable humanities research education.

How would this be possible? Through a return to a sort of pure scientific philology, one that holds that "materials are preserved because their simple existence testifies that they once had value, though what that was we may not - may never - know" (McGann). Philology brings to us a knowledge that is testimonial in nature. McGann recalls the great American poet Charles Reznikoff, 
author of a monumental work entitled Testimony in which he retells stories he had discovered while working on court records. He focuses on the stories themselves, omitting any sort of judgment and avoiding any form of poetic embellishment in an attempt to be as faithful as possible to the words of the original witnesses. McGann's promotion of a return to a philology that is scientifically oriented is timely, as it is related to Stanley Fish's campaign in favor of an interpretation based on critical inferences rather than on numbers and quantitative data about a text or a series of texts ("Mind Your P's and B's: The Digital Humanities and Interpretation").

Stanley Fish criticizes the rift of infinite interpretative possibilities opened by computer-assisted analysis and discusses their theoretical premises. First comes the idea of the death of the author, the end of the "myth" of the stand-alone, masterful author that is supposed to be exhibited as a pure fiction by the new forms of communication, from blogs to hypertext, that have emerged with the development of digital technology. Secondly, there is the idea that there is no longer any text to point to because it "exists" only in a state of perpetual alteration. As Kathleen Fitzpatrick states, "Digital text is, above all, malleable ... there is little sense in attempting to replicate the permanence of print in a medium whose chief value is change" (69). Fitzpatrick insists that there is still a place for individual authors and single texts, but that the individual will be integrated in "a fertile community composed of multiple intelligences, each of which is always working in relationship with others" (74).

Not sharing the practical and theoretical premises of digital humanities, Stanley Fish poses an important question that is at the core of Humanist Studies \& the Digital Age: "Does the digital humanities offer new and better ways to realize traditional humanities goals? Or does the digital humanities completely change our understanding of what a humanities goal (and work in the humanities) might be?" ("The Digital Humanities and the Transcending of Mortality"). The reader will find provisional and partial answers to these broad questions in the essays and projects presented in this issue, including the Princeton Dante Project, Cervantes Project - Texas A\&M University, The University of Oregon Petrarch Open Book, and the Scuola Normale Superiore di Pisa, Italy, Orlando Furioso Project. To this list one could add other projects that have undertaken pioneering work in the field of digital humanities, such as the Decameron Web and the Pico Project developed at Brown University. In different ways, these projects are hypertextual in nature and follow an open access philosophy, making available on the Internet some of the major classics of European and Western tradition in digital copies of manuscripts, incunabula, and modern books. They take on very seriously the challenge of our time, the preservation of our cultural memory, pointed out by Jerome McGann, and show how a hypertext digital project not 
necessarily means the demise of the author or the disappearance of the text as feared by Stanley Fish. On the contrary, a hypertext approach allows us today to see the evolution of a text from one technology to another, enabling in some cases a genealogical rendering of the text we are reading.

The fact that these projects take advantage of digital technology to include translations, commentaries, and intersemiotic transpositions adds more layers of signification to the text. This should be considered a positive integration to be welcomed and not feared. The early printing industry faced similar problems and addressed them in ways that are not so different from what digital hypertexts built around the classics are trying to accomplish: an intersemiotic dialogue between text and image, an increase of the circulation of these texts, and a democratization of the audience. The study of the rapport between texts and images is at the core of the Ariosto Project developed by the Centro di Elaborazione Informatica di Testi e Immagini nella Tradizione Letteraria (CTL); however, all the projects presented in this issue include intersemiotic apparatuses. The importance of philology has been stressed above all by the Oregon Petrarch Open Book in an article published in the first issue of this journal, "Return to Philology and Hypertext in and around Petrarch's Rvf," and is reiterated in the current issue with the presentation of the editio princeps of Petrarch Canzoniere, the Incunabulum Queriniano $G \vee 15$. This work is a perfect case in point, including images and marginal annotations for each poem and offering an inspiring and creative approach that is still valid in the digital world.

Digital projects such as the Oregon Petrarch Open Book allow scholars and students to appreciate in an unprecedented way the crucial and vital element of "writing practice" at the core of Petrarch's Canzoniere. Reading different versions and incarnations of the text in different formats leads scholars and students to concretely realize in what ways and forms a classic such as Petrarch is "contemporary" to the future. Petrarch writes not only to create a living text, but also to give birth to something that is projected into the future, beyond the historical perspective, something that may overcome the limits of the present (Pontiggia 1998, 58; Pontiggia 2004, 128-32). In his famous Posteritati, an autobiographical letter to posterity (Petrarca 1990), Petrarch shows that what he has to offer to the future is not a vision of divine wisdom but an account of his life full of uncertainty and restlessness. For Petrarch the wisdom that one can achieve coming of age and maturing is always "human" and never completed. In this letter, he also speaks of his love for the ancients that moves him to reject the present age and to continually attempt to live in spirit in other ages and to look into the future. Petrarch points here to the mysterious presence of the future in the present and to the alterity of an element in his life and intellectual research always resistant to writing and current human 
understanding.

The Posteritati shows how the poet was aware that the ancient classics were to him "contemporary to the future." In this letter, the founder of what we now call "humanism" suggests that the humanae litterae and the ancient manuscripts were important to him not just for their ability to help in understanding the present age, but also and above all, for the difference that they represented, for their not yet fully developed and understood meaning. Petrarch, too, considers himself as a classic, the first of the "modern" classics, and precisely for this reason in his Posteritati he asks the reader to consider him contemporary to the future. From this perspective, it is not important to look just for the contemporary, present value of Petrarch; rather, reading him, as any other classic, we should ask ourselves the following crucial question: "Are we contemporary to Petrarch?" In other words, in our reading and interpretation, are we addressing and keeping alive that projection into the future that the classics conceal as a treasure?

Material philology and e-philology provide the solid ground on which the idea of classic as "contemporary to the future" may be implemented. Material philology supports this idea by pointing to the fact that the Canzoniere were never a bound book during Petrarch's lifetime but remained full of continuous erasures and revisions, excluding the formal closures typical of medieval manuscripts. Ephilology further enhances this idea by providing the unprecedented availability of versions of the $R v f$ and encouraging an interactive and fluid approach that resists easy classification according to traditional categories and hierarchies. This does not mean that the text of the Canzoniere has been neglected in favor of a plurality of indistinct textualities but that we are in the position now to appreciate the evolution of the text and its metamorphoses. Moreover, the transmission of our cultural heritage in digital format gives us the opportunity to rethink the major tenets of the idea of humanism in which we grew up. Annotating and encoding the texts of the past, to keep alive their being contemporary to the future, should lead us to consider what we have lost in our engagement with the things that gave our lives purpose. Most importantly is our relationship to nature, which has been a source of meaning for centuries as the great classics of world literature testify. Hence, the need for reading our culture's classics anew, paying attention not just to a dialogue among authors but also to more than human sources of meaning, thereby becoming able once again to be drawn into intense connection with the wonder and beauty of the natural world.

The current issue of our journal includes the presentation of some other interesting projects that contribute to emphasize the innovative vitality of digital 
humanities. First the GIS Forma Urbis Romae Project that intends to create a layered history of Rome by updating Forma Urbis Romae, the cartographic masterpiece of ancient Roman topography published in 1901 by archeologist Rodolfo Lanciani. The second project is the literary magazine Griselda online a noteworthy hypertext experiment that among various initiatives promotes an original digital literary history of Italian literature. Finally, we decided to publish in this section of our journal the Introduction to the Chinese translation of Pico della Mirandola's Oration on the Dignity of Man (1496), the Manifesto of Renaissance Humanism. Pier Cesare Bori, the author of this Introduction, a dear friend of ours, sadly died at the end of 2012. He was the protagonist of the Pico Project developed at Brown University. We dedicate this issue of our journal to his memory.

In closing this brief editorial, let me remind you of the topic for the 2014 issue of Humanist Studies \& the Digital Age: "Lector in Rete: Figures of the Reader in Digital Humanities," which will address the complex questions of readership in digital projects.

\section{Works Cited}

Connerton, Paul. How Modernity Forgets. Cambridge, UK: Cambridge University Press, 2009. Print.

Dane, Joseph A. The Myth of Print Culture: Essays on Evidence, Textuality, and Bibliographical Method. Toronto: University of Toronto Press, 2003. Print.

Fish, Stanley. "The Digital Humanities and the Transcending of Mortality."

Opinionator, New York Times. 09 Jan. 2012. Web. 02 Feb. 2013.

- - . "Mind Your P's and B's: The Digital Humanities and Interpretation."

Opinionator. New York Times. 23 Jan. 2012. Web. 02 Feb.2013.

Fitzpatrick, Kathleen. Planned Obsolescence: Publishing, Technology, and the Future of the Academy. New York: New York University Press, 2011. Print.

Lollini, Massimo. "Return to Philology and Hypertext in and around Petrarch's Rvf."

Humanist Studies \& the Digital Age. 1.1 (2011). Web. 15 Sep. 2011.

<http://journals.library.oregonstate.edu/hsda/article/view/1101>.

McGann, Jerome. “Memory Now.” 4Humanities.Web. 02 Feb. 2013.

<http://4humanities.org/2012/08/jerome-j-mcgann-memory-now-2/>

-_- Radiant Textuality. Literature since the World Wide Web. New York: 
Palgrave/St Martins, 2001. Print.

Petrarca, Francesco. Canzoniere; Trionfi. Cur. Cristoforo [Berardi?]. Venezia: Vindelino da Spira, 1470. Incunabulum Queriniano G V 15. Queriniana Library, Brescia. Print. - - C Canzoniere. Codex Queriniano D II 21. Queriniana Library, Brescia. Print.

- - . Il Canzoniere. I Trionfi. Edizione anastatica dell'incunabulo queriniano G.V. 15 (Venetia Vindelino da Spira, 1470). Brescia: Grafo, 1995. Print.

- - Posteritati. Rome: Salerno, 1990. Print.

Petrarca, Francesco, and Gino Belloni. Rerum Vulgarium Fragmenta: Codice Vat. Lat. 3195 : Commentario All'edizione in Fac-Simile. Roma: Antenore, 2004. Print. Pontiggia, Giuseppe. I contemporanei del futuro. Milan: Mondadori, 1998. Print. "La Contemporaneità dell'antico." Il residence delle ombre cinesi.

Milan: Mondadori, 2004. 101-35. Print. 